\title{
Investigating the Attitude of PCG University Students Towards their Parents and Towards Marriage
}

\author{
Anıl Görkem ${ }^{1} \&$ Ayşe Bengisoy ${ }^{2}$ \\ ${ }^{1}$ Department of Psychological Counselling and Guidance, European University of Lefke, Lefke, TRNC, Turkey \\ ${ }^{2}$ Department of Psychological Counselling and Guidance, European University of Lefke, Lefke, TRNC, Turkey \\ Correspondence: Anıl Görkem. Department of Psychological Counselling and Guidance, European University of \\ Lefke, Lefke, Cyprus via Mersin on Turkey. Tel: 90-548-880-6969. E-mail: asayilir@eul.edu.tr
}

\author{
Received: October 31, 2017 Accepted: November 13, 2017 Online Published: January 26, 2018 \\ doi:10.5539/hes.v8n1p18 \\ URL: http://dx.doi.org/10.5539/hes.v8n1p18
}

\begin{abstract}
The aim of this study is to investigate students in classes 1-2-3-4, studying Pyschological Guidance and Counselling (PGC) at a university in T.R.N.C. (Turkish Republic of Northern Cyprus) in their relationships with their parents and their attitudes towards marriage. The study includes 325 students and was conducted during the spring of 2015-2016. 'Personal information forms', 'İnönü Marriage Attitudes Scale, 'Attitudes towards Parents Scale I and II' have been used in order to collect research data. The viewpoints of the student PCG group, who work with child and family, have been particularly focused in connection to all of these. The findings revealed that female students' attitudes towards their mothers are better compared to that of male students. However, in terms of gender, no connection was found between attitude towards their father and their attitude towards marriage. As female PCG students' attitude towards their mother increases, so too has their attitude towards their father and their attitudes towards marriage. For the men whose parents are still together (not separated), there is no link between their strong attiudes towards their parents and their attitude towards marriage. It has come to light that female students, whose parents are separated, have a stronger attitude towards their mother and father. No connection was found between the students' parents being married or having separate living arrangements and the students' gender. Male students with parents who live separately have a stronger approach towards their their mother and father.
\end{abstract}

Keywords: parent relationship, marriage, attitude towards marriage

\section{Introduction}

Family, parents and the upbringing of children are the most important factors that contribute towards forming a healthy society (Çaylıoğlu, 2002). Attitudes and relationships within the family affects all aspects of a child's development (Amato, 2008). As an individual develops physiologically, socially and psychologically, their attitude towards society is also affected (Onur, 2003). The mother, father and spouse are familiar with their roles and responsibilities within the family (İmamoğlu, 1991). Parents' attitudes affects all areas of an individual's life. An individual that first learns sociability within the family develops friendships and relationships with others (Ondaş, 2007). Family attitudes towards the individual's self-development (Kayhan 2011) is effective in developing positive personality traits (Kayhan ve Seçkin 1999). When an individual feels ready and realises the necessity of actualising their social roles within society, then they feel a need to choose a fitting spouse (Kıliç, Kaygisız, Tortumluoğlu, 2007).

Freud believes that, an individual expresses the closeness they feel towards their parents and positive admiration they have for them, by choosing a partner who reflects their similar characteristics; daughters in relation to their fathers and sons, their mothers (Özgüven 2000). According to the family systems theory, there are responsibilities that guarantee balanced familial relationships and unifies the family and when every family member brings forth these responsibilities, relationships thrive (İmamoğlu, 1991). In Bowen's family closeness approach, the only way to solve problems is by recognising the need for a change in pattern, instilled by previous family units (Nichols and Schwartz, 1997). A model has been developed that examines what the boundariest of the relationship between structural family counselling, parents and children should be. When there are clear boundaries between parent and child accompanied by a healthy level of compassion, healthy attitudes ensue. If there is a problem with this balance and a child embodies the role of a parent and lives within unhealthy boundaries, their own parent and spousal roles will also be affected (Nazli, 2000). 
The experiential-humanistic approach, which expresses the importance of communication and relationship patterns within the family, also defends the notion that families sharing their emotions and humour with each other appropriately is healthy (Gladding, 2002). Systematic theory of family deals with functional and dysfunctional life within family, as well as emotional and intellectual structure. This theory also encompasses the idea that family dynamics can change and that children's own family-building processes become efficient (Carr, 2009). Accordingly, attitudes and experiences between parents and children are significantly important (Özgüven, 2009). Cognitive behavioural theory defends that - dating, marriage, having children, changing residencies, changing professions, the period where children are at school and the period where children leave home and retirement begins - can end up in a dysfunctional state. If the dysfunctional period does not improve, this can be carried over to the next stage. As the social learning theory supports, during this long period of time, incorrect attitudes the individual learns will reflect badly when said individual has their own spouse (Smith and Stevens-Smith 1992).

As a parent raises their children, their attitudes need to nourish feelings of being loved, protected and respected. If the child feels the need to be perfect, however, and get the impression that imperfection means they won't be loved, they will feel burdened with feelings of worthlessness, insufficiency and guilt (Gladding, 2002). In Bener and Günay's (2012) study on young marriage and attitude towards family life, the findings show that when you look at university students' attitudes towards choosing a spouse and marriage, there is a traditional point of view, i.e. there are no concerns with marriage and choosing a spouse. In Burcu et al.'s (2015) study, they reached the conclusion that women with viewpoints linked to traditional cultural characteristics towards marriage, (İmamoğlu, 2000) especially at a young age was largely positive. It is thought that a significant effect on marriage is culture. In particular, a viewpoint has developed that honour should be protected, rather than being an economic burden on their family, one should leave home and start their own life.

\section{Method}

The focus group: PCG students in classes 1-2-3-4 at an Education Faculty of a T.R.N.C university in the Spring semester of 2015-2016 academic year participated in the study. A total of 325 students participated in the study on a voluntarily basis. 'Personal information forms', 'İnönü Marriage Attitudes Scale, 'Attitudes Towards Parents Scale I' and 'Attitudes Towards Parents Scale II' have been used in order to collect data. First of all, permission was granted from the relevant authorities before collecting data. Then, resarchers talked with course teachers, and informed them about the application of the inventories at the end of the lesson. To achieve the highest participation rate, reasrches preferred to employ the inventory at the end of the lesson. Inventories were applied to four branches of classrooms of the same course. Resarchers explained the aim of the study to students and then announced students that the participation was voluntary. Inventory application was completed within three days and data were collected from all participants. Scale applications took 45 minutes of the students. In the following table, demographic characteristics of the students' are given.

Table 1. Demographic Characteristics

\begin{tabular}{ll}
\hline Demographic Characteristics & $\mathrm{N}$ \\
\hline Gender & \\
Female & 158 \\
Male & 167 \\
Parents' Marital Status & \\
Married & 294 \\
Separated & 31 \\
Guardian & \\
Birth parents & 232 \\
Only birth mother & 58 \\
Stepmother & 4 \\
Only birth father & 4 \\
Stepfather & 2 \\
Grandparents & 19 \\
A minder & 2 \\
Birth father + stepmother & 1 \\
Total & 325 \\
\hline
\end{tabular}

As shown in Table 1, 167 males, 158 females took part in the study. A majority of these students were raised at home with both their birth parents. 


\subsection{Data Collection Tools}

Information Form: This mainly addressed the student's age, gender, number of siblings and details about their parents (age, marital status, guardian, level of education, etc.)

‘İnönü Marriage Attitude Scale' (IETÖ); A valid and reliable study developed by Bayoğlu and Atlı (2014) with the purpose of measuring young and old individuals' attitudes towards marriage were also used in the present study. 21 questions with an likert-type answer scale of 1-5: (1) completely disagree (2) slightly disagree (3) slightly agree (4) agree, (5) definitely agree. High scoring questionnaires showed a positive atitude towards marriage, and low scoring questionnaires showed a negative attitude towards marriage.

'Attitude Towards Parents Scale I'; A valid and reliable scale reflecting individuals' positive-negative attachment towards their 'mothers' was used. Students answered the scale based on their thoughts of their mothers by shifting to age sixteen years old and younger. The scale is a likert-type scaling made of 25 statementsr. The choices were as follows: (3)'completely accurate', (2)'slightly accurate', (1)'not accurate', (0)'completely inaccurate'. Some of the statements were pointed on a reverse scale. These statemtns were: '2.,4.,8.,9.,10.,13.,14.,16.,18.,19.,20.,23. and 24. The statemnts 8.,9.,10.,13.,19.,20.,23. found on the scale 'overprotective', the other statements were regarding attention and control.

'Attitude Towards Parents Scale II'; This scale is similar to 'Attitude Towards Parents Scale I' but focuses on measuring the individuals' attitudes towards their fathers'.

All Scales and information form are given to all students at the same time. The form and scales were created in the form of a booklet, and then were distributed to the students. Each scales' directives was given to the students in 5 minutes. Students did not write their names on the booklet.

\subsection{Data Collection Process and Analysis}

Data was collected by a research group compiled of volunteers who first expressed a desire to take part. After information on the research was shared, research materials were carefully distributed. The research was carried out amongst 325 volunteer PCG at an Education Faculty at a T.R.N.C university. The data was analysed using the program SPSS. Data was analysed using descriptive statistical methods (frequency, percentage, mean, standard deviation) as well as the One Sample Kolmogorov-Smernov Distribution Test to determine whether the data was distributed. To determine the scale of interpersonal relationships, the Kruskal Wallis $\mathrm{H}$ test non-parametric and ANOVA analysis for Pramatrik. Results $\mathrm{p}<0.05$ was considered significant. (1)

\section{Results}

Table 2. PCG department students' Attitude Towards Parents Scale and ve İnönü Marriage Attitude Scale, General Points Average and Standard Deviation values

\begin{tabular}{llllll}
\hline & N & Av. & Standard Deviation & Min. & Max. \\
\hline Mother att. & 325 & 52,0492 & 10,97658 & 9,00 & 79,00 \\
Father att. & 325 & 41,0369 & 7,66537 & 17,00 & 76,00 \\
Marriage att. & 325 & 81,3938 & 16,23321 & 21,00 & 129,00 \\
\hline
\end{tabular}

As seen in the table, the students' attitude towards marriage and attitude towards their mothers scale results' average scored high.

Table 3. Table 2. PCG department students' Attitude Towards Parents Scale and ve İnönü Marriage Attitude Scale distribution analysis

\begin{tabular}{lccc}
\hline & \multicolumn{3}{c}{ Mother att.Father att.Marriage att. } \\
\hline $\mathrm{N}$ & 325 & 325 & 325 \\
Kolmogorov-Smirnov Z1,648 &, 810 & 1,356 \\
Asymp. Sig. (2-tailed) &, 009 &, 528 &, 051 \\
\hline
\end{tabular}

The results show that Mother Attitude Scale doesn't show normal distribution, Father Attitude and Marriage Attitude does show normal distribution. Consequently, Mother Attitude was put through the Mann-Whitney U test, the others were analysed using t-test and ANOVA. 
Table 4. PCG department students' Attitude Towards Mother Totals and relationship with gender

\begin{tabular}{llllll}
\hline & gender & $\mathrm{N}$ & Row av. & Row totals & $\mathrm{P}$ \\
\hline \multirow{3}{*}{ Mother att. } & female & 158 & 175,00 & 27649,50 & .033 \\
& male & 167 & 151,65 & 25325,50 & \\
& Total & 325 & & & \\
\hline
\end{tabular}

As seen in the table, the attitude towards their mothers scored higher amongst the femaile students than the male students. There was no correlation between attitudes towards father, marriage and gender. At the same time, no correlation was found between gender and marriage status of the students' parents.

Tablo 5. PCG department's female students with parents not separated attitudes towards parents scale average and standard deviation values

\begin{tabular}{llll}
\hline & Average & Std. Deviation & $\mathrm{N}$ \\
\hline Mother att. & 53,25 & 11,08766 & 143 \\
Father att. & 42,20 & 7,56433 & 143 \\
Marriage att. & 80,21 & 15,99962 & 143 \\
\hline
\end{tabular}

As shown in Table 5, the average atitude towards marriage was high amongst students whose parents live together.

Table 6. Relationship between - PCG department's female students with parents not separated - and attitude towards parents

\begin{tabular}{|c|c|c|c|c|}
\hline & & Mother att. & Father att. & Marriage att. \\
\hline \multirow{3}{*}{ Mother att. } & Pearson Correlation & 1 & $338^{* *}$ &, $202^{*}$ \\
\hline & Sig. (2-tailed) & &, 000 & ,016 \\
\hline & $\mathrm{N}$ & 143 & 143 & 143 \\
\hline \multirow{3}{*}{ Father att. } & Pearson Correlation &, $338^{* * *}$ & 1 & ,067 \\
\hline & Sig. (2-tailed) &, 000 & & ,429 \\
\hline & $\mathrm{N}$ & 143 & 143 & 143 \\
\hline \multirow{3}{*}{ Marriage att. } & Pearson Correlation &, $202^{*}$ & ,067 & 1 \\
\hline & Sig. (2-tailed) & ,016 & 429 & \\
\hline & $\mathrm{N}$ & 143 & 143 & 143 \\
\hline
\end{tabular}

$* * \mathrm{p}<0.001$

$* \mathrm{p}<0.005$

As seen in Table 6, as the attitude towards the mothers of female students in PCG department increases so does their attitude towards their father and towards marriage.

Tablo 7. PCG department's male students with parents not separated attitudes towards marriage scale average and standard deviation values

\begin{tabular}{llll}
\hline & Av. & Standard Deciation & $\mathrm{N}$ \\
\hline Mother att. & 51,01 & 10,37 & 151 \\
Father att. & 40,01 & 7,50 & 151 \\
Marriage att. & 83,65 & 15,97 & 151 \\
\hline
\end{tabular}

As noted in Table 7 PCG department's male students with parents not separated attitudes towards marriage scale averages are higher. 
Tablo 8. Relationship between -PCG department's male students with parents not separated attitudes towards parents - and attitudes towards marriage

\begin{tabular}{lllll}
\hline & & Mother att. & Father att. & Marriage att. \\
\hline \multirow{3}{*}{ Mother att. } & Pearson Correlation & 1 &, $225^{* *}$ &, 046 \\
& Sig. (2-tailed) & &, 005 &, 577 \\
& $\mathrm{~N}$ & 151 & 151 & 151 \\
\hline \multirow{5}{*}{ Father att. } & Pearson Correlation &, $225^{* *}$ & 1 &,- 010 \\
& Sig. (2-tailed) &, 005 & &, 904 \\
& $\mathrm{~N}$ & 151 & 151 & 151 \\
\hline \multirow{3}{*}{ Marriage att. } & Pearson Correlation &, 046 &,- 010 & 1 \\
& Sig. (2-tailed) &, 577 &, 904 & \\
& $\mathrm{~N}$ & 151 & 151 & 151 \\
\hline
\end{tabular}

Relationship between - PCG department's male students with parents not separated attitudes towards parents - and attitudes towards marriage, has failed to show any correllation.

Table 9. PCG department's female students with parents separated attitudes towards parents and marriage scale average and standard deviation values

\begin{tabular}{llll}
\hline & Av. & Std. Deviation & $\mathrm{N}$ \\
\hline Mother att. & 54,06 & 10,47 & 15 \\
Father att. & 39,40 & 8,26 & 15 \\
Marriage att. & 75,53 & 13,89 & 15 \\
\hline
\end{tabular}

Table 10. Relationship between - . PCG department's female students with parents separated attitudes towards parents and towards marriage

\begin{tabular}{lllll}
\hline & & Mother att. & Father att. & Marriage att. \\
\hline \multirow{3}{*}{ Mother att. } & Pearson Correlation & 1 &, $527^{*}$ &,- 050 \\
& Sig. (2-tailed) & &, 044 &, 859 \\
& $\mathrm{~N}$ & 15 & 15 & 15 \\
\hline \multirow{3}{*}{ Father att. } & Pearson Correlation &, $527^{*}$ & 1 &,- 339 \\
& Sig. (2-tailed) &, 044 & &, 217 \\
& $\mathrm{~N}$ & 15 & 15 & 15 \\
\hline \multirow{3}{*}{ Marriage att. } & Pearson Correlation &,- 050 &,- 339 & 1 \\
& Sig. (2-tailed) &, 859 &, 217 & \\
& $\mathrm{~N}$ & 15 & 15 & 15 \\
\hline
\end{tabular}

*p $<0.05$

As noted in Tables 9 and 10, female students with separated parents attitude towards marriage scale averages are high and it can be said that there is correlation between attitudes towards mother and attitude towards father.

Table 11. PCG department's male students with parents not separated attitudes towards parents and attitude towards marriage scale average and standard deviation values

\begin{tabular}{llll}
\hline & Av. & Std. Deviation & $\mathrm{N}$ \\
\hline Mother total & 49,12 & 14,87 & 16 \\
Father total & 41,81 & 8,58 & 16 \\
Marriage att. total & 76,06 & 20,21 & 16 \\
\hline
\end{tabular}


Tablo 12. Relationship between - PCG department's male students with parents separated attitudes towards parents - and attitudes towards marriage

\begin{tabular}{|c|c|c|c|c|}
\hline & & \multicolumn{3}{|c|}{ Mother att.Father att.Marriage att. } \\
\hline \multirow{3}{*}{ Mother att. } & Pearson Correl & & $647^{* *}$ &,- 391 \\
\hline & Sig. (2-tailed) & & ,007 & ,134 \\
\hline & $\mathrm{N}$ & 16 & 16 & 16 \\
\hline \multirow{3}{*}{ Father att. } & Pearson Correl & $n, 647^{* *}$ & 1 &,- 279 \\
\hline & Sig. (2-tailed) & ,007 & & ,296 \\
\hline & $\mathrm{N}$ & 16 & 16 & 16 \\
\hline \multirow{3}{*}{\multicolumn{2}{|c|}{$\begin{array}{c}\text { Pearson Correl } \\
\text { Marriage att.Sig. (2-tailed) } \\
\mathrm{N} \\
\end{array}$}} & &,- 279 & 1 \\
\hline & &, 134 & ,296 & \\
\hline & & 16 & 16 & 16 \\
\hline
\end{tabular}

As shown in Tables 11 and 12, male students with separetly living parents have higher attitudes towards their mothers and fathers, respectively.

\section{Discussion}

In general, it has emerged that female students' attitude towards their mothers was higher than male students. It could be said that female children's relationships with their parents being stronger when compared to male children, can also be due to societal and culturual reasons. The gender differences in the students showed no correlation between attitude towards father and attitude towards marriage. So, it could be said that attitudes towards relationships with father do not affect perception towards marriage. But this is incontrast with Nazlı (2000). According to her resarch, when there are clear boundaries between parent and child accompanied by a healthy level of compassion, healthy attitudes must be regained. If there is a problem with this balance and a child embodies the role of a parent and lives within unhealthy boundaries, their own parent and spousal roles would also be affected.

As the attitudes of PCG department female students towards their mothers increases, so too it seems does attitudes towards fathers and towards marriage. That attitudes towards mother affect attitudes towards father and that this in turn make female children's attitude towards marriage positive cannot be denied. This is incontrast with Freud. He believes that, an individual expresses the closeness they feel towards their parents and positive admiration they have for them, by choosing a partner who reflects their similar characteristics; daughters in relation to their fathers and sons, as well as their mothers (Özgüven, 2000). With male students with parents that are not separated, as their attitude towards parents increases, there seems to be no correlation with their attitude towards marriage.

As shown in the results, female students in the PCG department whose parents are separated have high scale averages in attitudes towards marriage and it can be said that there is correlation between the students' attitudes towards their mother and their father.

Male students with parents that are separated also have higher attitudes towards their relationships with their mothers and fathers. Generally, when you look at it, you can come to the conclusion that female children who have positive attitudes towards their mothers also results in their attitudes towards thir father and to marriage positive. The fact cannot be escaped that the same cannot be said for male children.

It can be said that in the prevailing patriarchal Turkish societies, the female factor is in fact, with their attitudes towards relationships and perspectives towards marriage, quite effective, yet it is not obvious because it has been suppressed. This study sugegstes that parents' relations is important predictors of childrens perspectives on marriage. However, Burcu et al., (2015) found that, women with viewpoints were linked to traditional cultural characteristics towards marriage.

\section{References}

Bayoğlu, F. ve Atlı, A. (2014). İnönü Evlilik Tutum Ölçeği. Ege Eğitim Dergisi. sayı (15), 2:397-415.

Bener, Ö., \& Günay, G. (2012). Gençlerin Evlilik ve Aile Yaşamına İlişkin Tutumları. Karabük Üniversitesi Sosyal Bilimler Enistitüsü Dergisi. Cilt 2-sayı 1.

Burcu, E., Yıldırım, F., Sırma, S. Ç., \& Sanıyaman, S. (2015). Çiçeklerin Kaderi: Türkiye’de Kadınların Erken Evliliği Üzerine Nitel Bir Çalışma. Bilig Dergis, sayı, 73(63-98).

2001 Yılı Aile Raporu (2002). (Ed.Çaylığlu, İ.) Aile İçi İlişkiler Komisyonu. 3. Ailede Rol ve Sorumluluklar. T.C. Başbakanlık Aile Araştırma Kurumu Yayınları, Yayın No:120.Ankara. Beyda Ofset. 
Carr, A. (2009). The Effectiveness of Family Terapi and Systemic Interventions for Adult Focused Problems, Journal of Family Therapy.

Gladding, S. T. (2002). Family terapy: History and Practise (3 nd ed). Merrill Prentice Hall.

İmamoğlu, E. O. (1991). Aile İçinde Kadın-Erkek Rolleri. Türk Aile Ansiklopedisi. Ankara: Cilt 3, T.C. Başbakanlık Aile Araştırma Kurumu. Ankara Türkiye Yazarlar Birliği Vakfı.

İmamoğlu, O. (2000). Changing gender roles and marital satisfaction in Turkey. InGender and Identity Construction Eds. F. Acar, A. Ayata, (pp. 101-116).Netherlands: Brill Inc.

Onur, B. (2003). Gelisim Psikolojisi: Yetiskinlik, Yaslılık, Ölüm, , Ankara: İmge Kitabevi, 6. Bask1.

Özgüven, İ. E. (2000). Evlilik ve Aile Terapisi. Ankara: Pdram Yayınları.

Pınar, G. (2008). Üniversite Son Sınıf Öğrencilerinin Evliliğe Bakış Açısı. Aile ve Toplum Dergisi, 10:(4):49-60.

Nazlı, S. (2000). Aile Danışması. Nobel Yayınevi, Ankara.

Nichols, M., \& Schwartz, R. (1997). Family Terapy: Concepts and Methods. Boston: Allyn \& Bacon.

Smith, R. L., \& Stevens-Smith, P. (1992). Future projections formarrige and family counseling and therapy. In R. L. Smith ve P. Stevens-Smith, Family counseling and therapy. Ann Arbor.

Vefikuluçay, D. Zeyneloğlu, S. Eroğlu, \& K ve Taşkın, L. (2007). Kafkas Üniversitesi Son Sınıf Öğrencilerinin Toplumsal Cinsiyet Rollerine İlişkin Bakış Açıları. Hacettepe ÜniversitesiSağlık Bilimleri Fakültesi Hemşirelik Dergisi, 14(2), 26-38.

Bener, Ö. ve Günay, G. (2012). Gençlerin evlilik ve aile yaşamına ilişkin tutumları. Karabük Üniversitesi Sosyal Bilimler Enstitüsü Dergisi, 2(1), 1-27

Büyüköztürk, Ş. (2012). Veri analizi el kitabı. Ankara: Pegem Akademi Yayınları.

Kayhan, Ü. (2011). Aile Yapısı ve İlişkileri. Eskişehir: Anadolu Üniversitesi Açıköğretim Fakültesi Yayınları.

Kayhan, Ü. ve Seçkin, N. (1999). Aile yapısı. Eskişehir: Anadolu Üniversitesi Açıköğretim Fakültesi Yayınları.

Kılıç, D., Kaygusuz, C., Bağ, B., ve Tortumluoğlu, G. (2007). Üniversite öğrencilerinin eş seçimine ve evliliğe ilişkin tutumları. Sağllk ve Toplum Dergisi, 17(1), 32-42.

Koçinoğlu, H. (1991). Sosyo ekonomik düzeyi farklı ailelerin evlilik konusundaki bilgi tutum ve tavırlarının saptanması. (Yayımlanmamış Yüksek Lisans Tezi). Gazi ÜniversitesiSosyal Bilimler Enstitüsü, Ankara.

Keklik, İ. ve Yıldırım, İ. (2012). Aile terapisi: tarihi -kuram ve uygulamaları. Ankara: PDREM Yayınları.

Ondaş, B. (2007). Üniversite öğrencilerinin evlilik ve eş Seçimi ile ilgili görüşlerinin incelenmesi, (Yayımlanmamış Yüksek Lisans Tezi), Gazi Üniversitesi EğitimBilimleri Enstitüsü, Ankara.

Özgüven, İ. E. (2009). Evlilik ve aile terapisi. Ankara: PDREM Yayınları.

Türkarslan, N. ve Süleymanov, A. (2010). Üniversite son sınıf öğrencilerinin evlilik konusundaki görüş ve düşünceleri- Azerbaycan ve Türkiye karşılaştırması.Karadeniz-Blacksea-Черное море, 05, 54-66.

\section{Copyrights}

Copyright for this article is retained by the author(s), with first publication rights granted to the journal.

This is an open-access article distributed under the terms and conditions of the Creative Commons Attribution license (http://creativecommons.org/licenses/by/4.0/). 